\title{
腰部椎間板症における特殊レ線撮影の比較検討
}

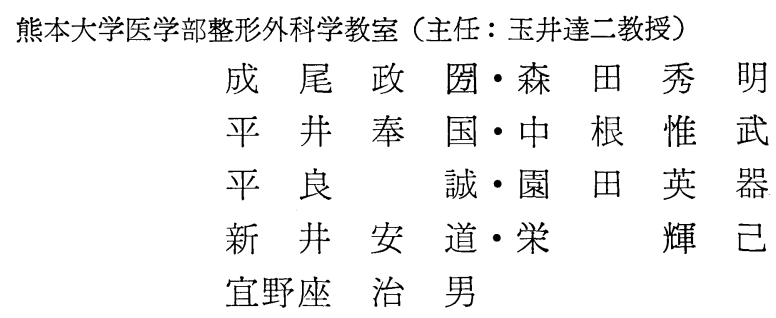

\section{Comparative Investigations of Special Contrast Studies on Lumbar Dics Lesion}

By

\author{
M. Naruo, H. Morita, Y. Hirai, N. Nakane, \\ H. Sonoda, Y. Arai, T. Sakae \& H. Ginoza \\ Dapartment of Orthopaedic Surgery, Kumamoto University \\ School of Medicine (Director: prof. T. Tamai)
}

\begin{abstract}
Venography, peridurography, Conray-myelography and discography are a X-ray diagnostic technique for a lumbar disc lesion. Twenty patients of lumbar disc lesion, all of whom were studied with these X-ray diagnostic technique, and treated by anterior remeval of disc and interbody fusion. The value of these techniques as a diagnostic aid was discussed. The discussion was supported by the result of comparative investigations between the findings of these special constrast studies and operation. The rate of coincidence between the two was as follows:

1 ) in 10 cases of $\mathrm{L}_{4-5}$ disc lesion: venography, peridurography and discography were $100 \%$. Conray-myelography was $40 \%$.

2) in 7 cases of $L_{5}-\mathrm{S}$ disc lesion : venography, peridurography and Conray-myelography were $71 \%$. Discography was $100 \%$.

3 ) in 3 cases of $\mathrm{L}_{4-5} . \mathrm{L}_{5}-\mathrm{S}$, double disc lesions : venography, peridurography, Conraymyelography and discography were $100 \%$.

The rate of coincidences of these special constrast studies in these 20 cases were as follows : venography (90\%), peridurography (95\%), discography $(100 \%)$ and Conray-myelography (60\%). From these comparative investigations, discography is seemed to be the most believable diagnostic technique for both $\mathrm{L}_{4-5}$ and $\mathrm{L}_{5}-\mathrm{S}$ disc lesions.
\end{abstract}

\section{はじめに}

脊椎管内諸疾患の診断には神経学的諸検査の他に, 補助診断法として, Dynamogram, Myelogram, Peridurogram, Discogram 等を必要とする症例があ る. 我々は Lumbago, Ischias の強い症例に対して Dynamogram により Instability の有無を検査し, 更に Periduro, Vonography を施行し, 必要に応じ て Discography を行ない, 症例によっては Conray-
Myelography を行なっている. てれ等の総合的分析 乙患者の職業, 年令, 性別等を考慮し, 術式の選択を 行なっている. 今回は前方椎体固定術を行なった症例 のうち, 後方へルニアを確認し得た 20 例について, 乙れ等の補助診断法の診断学的価值について, 比較検 討した結果を述べる.

Venography は経棘突起性に 行ない，造影が上下 椎間の変化传限られるので, 正確を期して, $\mathrm{L}_{4}, \mathrm{~L}_{5}$ の 棘突起から施行し, 前後像に挹ける前内椎骨静脈叢の 
表 1 Coincidence of Dynamo and Special Studies

\begin{tabular}{|c|c|c|c|c|c|}
\hline Disc lesion Level & Dynamo. & Veno. & Periduro. & Myelo. & Disco. \\
\hline $\mathbf{L}_{4-5}$ & $7 / 10$ & $10 / 10$ & $10 / 10$ & $4 / 10$ & $10 / 10$ \\
\hline $\mathrm{L}_{5-} \mathrm{S}_{1}$ & $3 / 7$ & $5 / 7$ & $6 / 7$ & $5 / 7$ & $7 / 7$ \\
\hline $\begin{array}{l}\mathrm{L}_{4-5} \\
\mathrm{~L}_{5-} \mathrm{S}_{\mathrm{I}}\end{array}$ & $\begin{array}{c}1 / 3 \\
2 / 3\end{array}$ & $3 / 3$ & $3 / 3$ & $3 / 3$ & $3 / 3$ \\
\hline Total & & $18 / 20$ & $19 / 20$ & $12 / 20$ & $20 / 20$ \\
\hline
\end{tabular}

$\mathrm{L}_{4-5}$ : Disc Lesion 10 Cases, $\mathrm{L}_{5-} \mathrm{S}_{1}$ : Disc Lesion 7 Cases

$\mathrm{L}_{4-5}, \mathrm{~L}_{5-} \mathrm{S}_{1}$ : " 3 Cases, Total : 20 Cases

不整, 㹨窄, 断絶, 欠損, 椎間静脈の細狭, 欠損, 断 絶, 圧排, 前外後外椎骨静脈叢の異常吻合, 血管の異 常走行等について検討した.

Peridurography は原則として仙骨裂孔から行な い, 前後, 両側面, 両斜位の計 5 枚を撮影し, 前後造 影条の 欠損, 後方膨隆化, 不明瞭化, 帯状像部分欠 損, 神経根, 根のう像欠損の有無等を検討した.

Conray-Myelo は二管球方式により, 約 $15^{\circ}$ 頭側 高位の腹臥位にて前後, 左右像を撮影後, 起立位にお ける最大前後屈側面撮影を行ない，症例によっては両 斜位撮影も加え，乙れ等の所見を I 型：根のう像欠 損, II 型：半月型陰影欠損, III型：砂時計状狭窄, IV 型：完全ブロックの 4 つの型に分け，更に脊髄レリー フの有無により A， Bに分ける辻の方法に従って分類 した.

Discography は K. U 式二重造影針を用い, 経硬 膜的に 3 椎間に行い, 造影時の Pain response, Resistance を詳細に検討し, 辻の方法により分類し た.

\section{結果}

$\mathrm{L}_{4}$ - $\mathrm{L}_{5}$ 間のヘルニアは 10 例 で, Veno Periduro Disco の像はヘルニアの存在部位と $100 \%$ 一致を 見, Conray-Myelo では False negative を60\%に 認めた。

$\mathrm{L}_{5}$-S 間のヘルニアは 7 例で Veno 5 例 $(71 \%)$ Periduro 5 例 (71\%) Myelo 5 例 (71\%) Disco 7 例 $(100 \%)$ に一致を認めた.

$\mathrm{L}_{4}-\mathrm{L}_{5}, \mathrm{~L}_{5}$ - $\mathrm{S}$ の Double herniation は 3 例で, Veno Periduro Myelo Disco 共に $100 \%$ の一致を 見た.とれ等を総合すると表 (1) に示す様に, Veno 18 例 (90\%) Periduro 19 例 (95\%) Myelo 12 例
(60\%) Disco 20 例 (100\%) にヘルニア存在部位と の一致を見た. 次に 2 症例を示す.

症例 1 は $\mathrm{L}_{4}$ の軽度の Pseudo-listhesis を伴い Massive herniation を認めた症例で, Veno では $\mathrm{L}_{4}$ $-\mathrm{L}_{5}$ 前内椎骨静脈叢欠損, 右椎間静脈欠損, 前後外 椎骨静脈叢への異常吻合を認める. Periduro では $\mathrm{L}_{4}-\mathrm{L}_{5}$ 間に一致する前後造影条の 後方膨隆像を認め Disco では高度変性を有する前後方脱を認める. 症例 2 は $\mathrm{L}_{4}-\mathrm{L}_{5}$ 間のヘルニアで, False negative my-

Case 25 K.Y. 47 y male L45 Prot.

E.P.D.

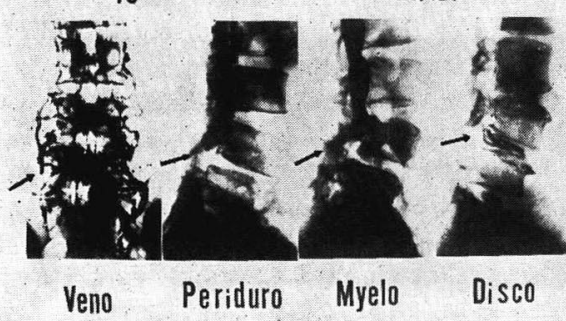

症 例 1

Case 18 T.N. $40 \mathrm{y}$ male
L45 Prot.

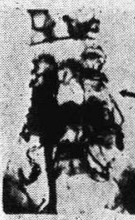

Veno

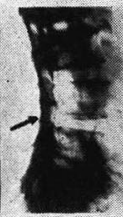

Periduro
E.P. D.

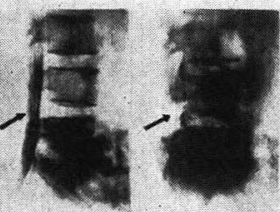

Disco 
elo の症例であり, Veno では左 $\mathrm{L}_{4}-\mathrm{L}_{5}$ 間の椎間静 脈欠損, 前内椎骨静脈叢欠損を認めDisco では高度 の変性と Epidural Dye を認める.

\section{考察}

Venography Peridurography は外来において簡 単に行なう事が出来, しかも副作用が殆んどないのが 利点である.

Venogram は椎間板変性の 程度と 相関関係がある 事は中島, 伊藤等が報告しているが, 特に偏側性ヘル ニアに診断学的価值が高く, 又前方侵入を考慮した場 合の総腸骨静脈のレベル確認にもなる.

Peridurography は Sicard and Forestier によ り 1921 年に初めて報告されて以来, Sanford, Junge, W. Luendijk 等の報告があり, 本邦であ前田, 岩原, 中本, 若松, 山手, 諸富, 山村, 森, 林等多くの報告 がなされ, その診断学的価値は高く評価され, 兼松は 診断学的価值之読影上の問題点にふれ, 偏側性ヘルニ アでは油性ミエロより描出性にすぐれていると述べ, 又 Double herniation の診断は異常像がヘルニア自 体の大きさと共に周囲の状況によっても影響をうける ので, 他椎間に迄影響像が出現する事が多く, この影 響像を考慮すると, 不可能であると述べている. 我々 の症例では Double herniation は 3 例共に完全な一 致を見た。

水溶性の Myelography は 1964 年 Campbell 等 が始めて Conray-Myelo を発表し, Myelo 後一過性 の筋痙攣, 知覚異常等が見られ, 臨木応用には制限が あると述べた.

1968 年 DavisはDepo-Medrol 併用による本検査を 行なったが，副作用は変らなかったと述べている．そ の後欧米において多くの報告がなされ，本邦であ加藤 の報告以来, 広く行われている. 加藤は水溶性, 油性 ミエロの比較を行ない, 大きな腰部椎間板ヘルニアで は硬膜のう, 馬尾神経の圧迫が見られ, Myodil-Myelo であ容易に診断可能であるが，小さなへルニアの症 例, 特に外側に存在する場合, その診断能力は劣ると 述べ, Conray-Myelo の価値について述べている. 又 Davis は腰部椎間板ヘルニアの同一症例に, 間隔 をおいて Pantopaque Myelo, Conray-Myelo を施 行し, 前者では斜位像であ根のう像が中断され欠如し ていたが, Conray ではその根のうは正常に造影され ており, 腰椎部 Myeloの “false positive”を少なく
するであろうと述べている.

しかし乍ら副作用として, 頭痛, 発熱, 嘔吐, 下肢 の間代性疰攣等を認める事があり, 特に Spondylo1isthesis, Postero-lateral recessus からの圧迫によ る Spinal Canal Stenosis の造影には注意する必要 がある様に思われる.

我々の 20 症例では $\mathrm{L}_{4}-\mathrm{L}_{5}$ 間に False negative が多く，乙れ等の症例によって診断学的価值について 論ずる事は早計であるが，前方法による手術を行なっ た症例に Protrusio type, 偏側性ヘルニアが多かっ たためとも思われる.

Discography は直接診断法として Lindblom (19 48）によって初めて報告されて以来, 欧米, 本邦にお いても広く行なわれている. Collis (1963) は Discogram itself + Pain response $=$ Final Diagnosis であると述べ, 造影時の Pain response, Resistance 等充分にチェックする必要がある.

合併症として脊髅炎, 椎間板炎, 人工的な椎間板へ ルニア, 変性等を併発する恐れがあるといわれている が, 我々は 26 ゲージの細い内套針を用いた二重針を 考案し現在迄数百例の経験を有するが，合併症は 1 例 あ経験していない.

Discogram はヘルニア腫瘤の 形状のみでなく，椎 間板の変性を知ると共に，いずれがより主体性を有す るかを知り, 手術々式の選択に必要かくべからざる検 查法と思われる.

\section{ま と め}

以上 4 つの特殊レ線撮影を行ない, 前方法により後 方ヘルニアを確認し得た 20 例について，乙れ等の診 断学的価值について比較検討した.

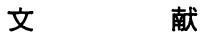

1) Amsler, F. R.: J. B. J. S. 49-A : 703-712, 1967.

2) Biasini, A.: Minerva. Chir. 10:491-498, 1955.

3) Fischgold, H.: Press me'd. 60:599-601, 1952.

4) Greitz, T.: Acta Radiol. $57: 353-365$, 1962.

5) Schobinger, R. A. \& Krueger, E. G.: Acta Radiol. Diagnosis. 1: 763-776, 1963.

6) Lessmann, F. P. \& Schobinger, R. A. : Acta Radiol. 44: 397-409, 1955. 
7）山崎：日整会誌. $28: 566-574,1954$.

8）星 - 他：日整会誌. $39: 210,1965$.

9) 伊藤 - 他：整形外科. 18:1255, 1967.

10）大谷：中部整災誌. $7: 22-37,1964$.

11）中島：日整会誌. $43: 15-35,1969$.

12）成尾-他：整形外科と災害外科. Vol. 20, No. 90-94.

13）紫崎 - 他: 臨床整形外科. Vol. 6, No. 2, 151 $-157,1971$.

14) Sicard \& Forestier: Rev. Neurol, S.1264: 1921.

15) Junge, H.: Fortshrist Rōntg, $77:$ 187-192, 1952.

16) Luenjirk, W.: Acta Radiol. Diagn. 5: 1051-1066, 1966.

17）諸富・他：中部整災誌. 11:807-809, 1968.

18）林：中部整災誌.14(1): 1-32, 1971 .

19）山村：日整会誌. 41：991-1008，1967.

20）横山：日整会誌. $18: 824-829,1943$.

21）山手・他：日整会誌. 31:310-311, 1957.

22）若松・他：日整会誌. 28：422-424, 1954.

23）前田：日外誌. $37: 146-264,1936$.

24）中本・他：日整会誌. 28：421-422，1954.

25）兼松.他：整形外科. Vol. 23, No. 4, 266$274,1972$.

26) Campbell, R. L. : Radiology. 85: 545-637, 1965.

27) Davis, F. M.: Radiology. 90: 705-710, 1968.

28) Caron, P.: J. Radiologie etd' Electrologie. $50: 157-162,1969$.

29）加藤 - 他：臨床整形外科. Vol. 5, No. 9, 712 $-727,1970$.
30) Lindblom: Acta Orthop. Scand. 17:231239, 1948.

31）辻・他：東日本整形外科学会発表. (1971).

32) Collis : Lumbar Discography. 1963.

33) Erlacher, P. H. : J. B. J. S. 34-B : 204-210, 1952.

発 信谷豊田病院 杉浦 皓

Peridurography では $\mathrm{L}_{5}-\mathrm{S}$ 間の影剤が不十分と なり易い，先生は優秀な診断率を示されたが何かての 点について良い方法があったらお教え下さい.

又 Discogram は針抜去後撮影されている様ですが 刺入孔よりの漏出は起りませんか.

発 言山口県立中央 弓削大四郎

ヘルニアの診断に, 脊椎静脈造影のような手技が必 要かどうかぎあんであると思うが.

解 答 熊大整形外科 成尾 政图

1）硬膜外造影は仙骨裂孔から原則として行い，造 影不良又不能の場合には, 腰部から行なっている.

2）椎間板造影は勿論針を刺入し造影した像も撮影 し, $0.1 〜 0.2 \mathrm{cc}$ 注入後針を抜いて撮影する.

3）我々は外来において, Veno, Periduro でチェ ックし, 特に前方法の適応には, Discography を行な っている. すべて Veno. Peridron, Myelo, Disco を施行している訳ではない. 